\title{
External Factors, Internal Factors and Self-Directed Learning Readiness
}

\section{Nurjannah Ramli ${ }^{1} \bowtie$ \\ Pudji Muljono ${ }^{2}$ (D) \\ Farit M. Afendi ${ }^{3}$}

'School of Business, Bogor Agricultural University, Indonesia

Email:nannaramli@gmail.com Tel:081342009115

${ }^{2}$ Faculty of Human Ecology, Bogor Agricultural University, Indonesia

Email:pudjimuljono@gmail.com

${ }^{s}$ Faculty of Mathematics and Natural Sciences, Bogor Agricultural University, Indonesia

Email:fimafendi@gmail.com Tel:08128592194.

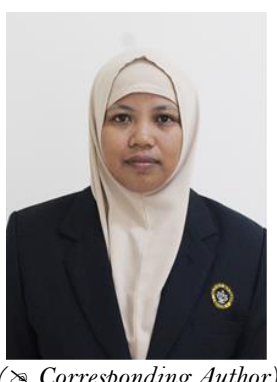

Corresponding Author

\begin{abstract}
There are many factors which affect the level of self-directed learning readiness. This study aims to investigate the relationship between external factors, internal factors and self-directed learning readiness. This study was carried out by using a census method for fourth year students of medical program of Tadulako University. Data were analyzed quantitatively using analysis tool of Structural Equation Modeling (SEM) with Partial Least Square (PLS) approach. Latent variables in this study consist of internal factors, external factors and self-directed learning readiness. The results of this study showed that as much as $24 \%$ of the variation in internal factors and $55.8 \%$ of the variation in self-directed learning readiness is could be explained by variations in the model. The external factors affected significantly on internal factors and self-directed learning readiness. The external factors have a direct positive affect to internal factors, while the external factors have indirect effect on self-directed learning readiness through internal factors mediation variable.
\end{abstract}

Keywords: External factor, internal factor, self-directed learning readiness.

Citation | Nurjannah Ramli; Pudji Muljono; Farit M. Afendi (2018) External Factors, Internal Factors and Self-Directed Learning Readiness. Journal of Education and e-Learning Research, 5(1): 3742.

History:

Received: 27 December 2017

Revised: 22 January 2018

Accepted: 26 January 2018

Published: 30 January 2018

Licensed: This work is licensed under a Creative Commons

Attribution 3.0 License $(\mathrm{cc})$ )

Publisher:Asian Online Journal Publishing Group
Contribution/Acknowledgement: All authors contributed to the conception and design of the study. This study contributes in the existing literature about self-directed learning readiness. The primary contribution of this study is finding that the internal factors is e mediator for the effect of external factors to the self-directed learning readiness

Funding: This study received no specific financial support.

Competing Interests: The authors declare that they have no conflict of interests.

Transparency: The authors confirm that the manuscript is an honest, accurate, and transparent account of the study was reported; that no vital features of the study have been omitted; and that any discrepancies from the study as planned have been explained.

Ethical: This study follows all ethical practices during writing.

\section{Contents}

1. Introduction

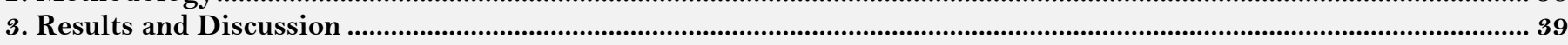

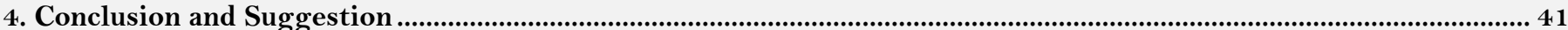

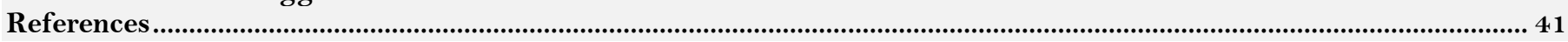




\section{Introduction}

Problem-based learning is one of the methods that can be applied in student centered learning. Problem-based learning method is a method of learning which demands the liveliness and independence of student in their study. One of the aims of implementing problem based learning is to build and develop students' learning in the field of psychomotor in terms of scientific reasoning, critical appraisal, information literacy, self-directed learning and lifelong learning. Self-directed learning is an important skill that students need to possess (Conradie, 2014) and capable of helping adults to feel safer during their learning period (Knowles et al., 2005). Self-directed learning is not only needed in the education world but also needed in the world of work, even the ability of self-directed learning has become a prerequisite to live in a rapid dynamic world with rapid changes (Levett-Jones, 2005).

Anyone can turn into self-directed learner; however, the level of their self-directed learning ability depends on many factors such as motivation for learning, self-confidence, conscience, experience, and intelligence (Cazan and Schiopca, 2014) which are collectively called readiness for self-directed learning. Wiley (1983) defined the selfdirected learning readiness as "the degree the individual possesses the attitudes, abilities and personality characteristics necessary for self-directed learning”.

Medical study program is the most in demand major for prospective students. Medical graduates are medical degree holder, if they do not enroll their education to professional level, they will find difficulties during seeking jobs. A candidate for medical degree holder must be prepared to be able to attend clinical education in professional program and physician competence exam to get doctor degree and able to implement life-long learning. Therefore, the students must have sufficient competencies that they obtained from the degree program of medicine; and one of them is self-directed learning readiness.

Since its establishment, Medical Program of Tadulako University (UNTAD) has applied the problem based learning method, however many obstacles were still perceived by students related to self-directed learning including the fourth year students. The obstacles namely lack of initiative and difficulties in managing their study time. Other problems were lack of students' awareness and misconceptions about self-directed learning. Therefore, it is important to acknowledge the factors affecting the self-directed learning readiness especially among the 4th year students before they continue their education in the professional physician program.

The implementation of problem based learning method which demands the students' activeness and independence in learning required an excellent awareness of self-directed learning readiness and the factors affecting the level of self-directed learning readiness. The factors that can affect the self-directed learning readiness are internal factors and external factors. The internal factors consist of physical health, leisure time availability, hobby or passion, self-maturity, and intelligence. The external factors consist of family and friends' support, faculty facilities, problems encountered, peer relationships, and the influence of parents and friends (Nyambe et al., 2016). The level of students self-directed learning readiness also can be influenced by family social support (Tarmidi, 2010) academic environment in terms of learning facilities and academic atmosphere (Leatemia et al., 2016).

The goal of this study was to investigate the relationship between external factors, internal factors and selfdirected learning readiness. The specific purpose of this study is:

1. Analyze the influence of external factors on internal factors and self-directed learning readiness of fourth year medical student of Tadulako University

2. Analyze the role of internal factors to the self-directed learning readiness of fourth year medical student of Tadulako University

\section{Methodology}

This study used quantitative methods with survey approach. The methods used to obtain data on influencing factors of the self-directed learning readiness to UNTAD medical students. Sampling technique was used by using total sampling technique. The data used in this study was primary data in terms of students' characteristic, internal factors, external factors and self-directed learning readiness. Primary data collection was carried out by survey method using questionnaire instrument.

Questionnaires for internal and external factors were developed based on the components that constitute external factors and internal factors that influence self-directed learning readiness called on relevant theoretical and research studies. The questionnaire for self-directed learning readiness was adopted from the self-directed learning readiness scale questionnaire for Nurse Education developed by Fisher et al. (2001) which has been reviewed by Fisher and King (2010). Questions in the questionnaire were presented in the form of closed questions organized by 5 -point Likert scale;

Scale 1 = very disagree,

Scale 2 = disagree,

Scale $3=$ neutral,

Scale $4=$ agree,

Scale $5=$ very agree.

Processing and data analysis was conducted descriptively quantitative by using Structural Equation Modeling (SEM) analysis tool with alternative method variance based or component-based SEM-called Partial Least Square (PLS) using Smart PLS version 2.0. The SEM analysis used to analyze the relationship between variables (constructs) studied. SEM is a multivariate statistical analysis method capable of testing complex research models simultaneously and analyzing variables that can't be measured directly. SEM is a more reliable, illustrative and robust method than regression techniques when modeling interaction, nonlinearity, measurement error, correlation error terms, and correlation between multiple latent independent variables with one or more latent variables dependent with multiple indicators (Jogiyanto, 2011).

In this study, there were three variables involved, namely one exogenous latent variable and two endogenous latent variables. The exogenous latent variable was external factors (EF). The endogenous latent variable were internal factor and self-directed learning readiness (SDLR). The external factors were academic environment (AE), family environment $(\mathrm{FE})$ and community environment $(\mathrm{CE})$. The internal factors were academic self-concept 
(ASC), achievement motivation (AM) and interest to learn (IL). The self-directed learning readiness was desire to learn (DL), self-control (SC) and self-management (SM).

\section{Results and Discussion}

\subsection{Structural Equation Modeling Analysis}

In SEM analysis in the partial least square approach, there were two types of model evaluation, namely the measurement model evaluation (the outer model evaluation) and the structural evaluation model (the inner model evaluation). The outer model or measurement model defines the relationship between the indicator and its latent variables. The outer model through the algorithm iteration, the parameter of the measurement model (convergent validity, discriminant validity, composite reliability and cronbach's alpha) is obtained including the value of $\mathrm{R}^{2}$ as the predictor model prediction parameter. Inner model or structural model predicted the causality relationship among the latent changing. Through the bootstrapping process, T-statistic test parameters were obtained to predict the existence of causality relationship (Jogiyanto, 2011; Abdillah and Jogiyanto, 2015).

\subsubsection{Outer Model}

Outer model evaluation or the measurement model used to mark the validity and reliability of the model. The measurement model of evaluation was conducted to assess the validity and reliability of the model. The validity test on the PLS is a test of stability validity consist of convergence validity test and discriminant validity test. Convergent validity test in PLS with reflective indicator is assessed based on loading factor value (relationship between indicator variables and latent variables). The reflexive size of the indicator with its construct is said to be high if it correlates or has a loading factor value of more than 0.7 with the construct to be measured. For early stage research of development, measurement scale with loading factor value of 0.5 to 0.6 is considered sufficient (Ghozali, 2008).

Based on outer model evaluation results with algorithms there are indicators in the initial measurement model (Figure 1) which has a loading factor value of less than 0.5 i.e. the community environment. The indicators are eliminated and then re-estimated to obtain the final measurement model. The re-estimation results are presented in Figure 2.

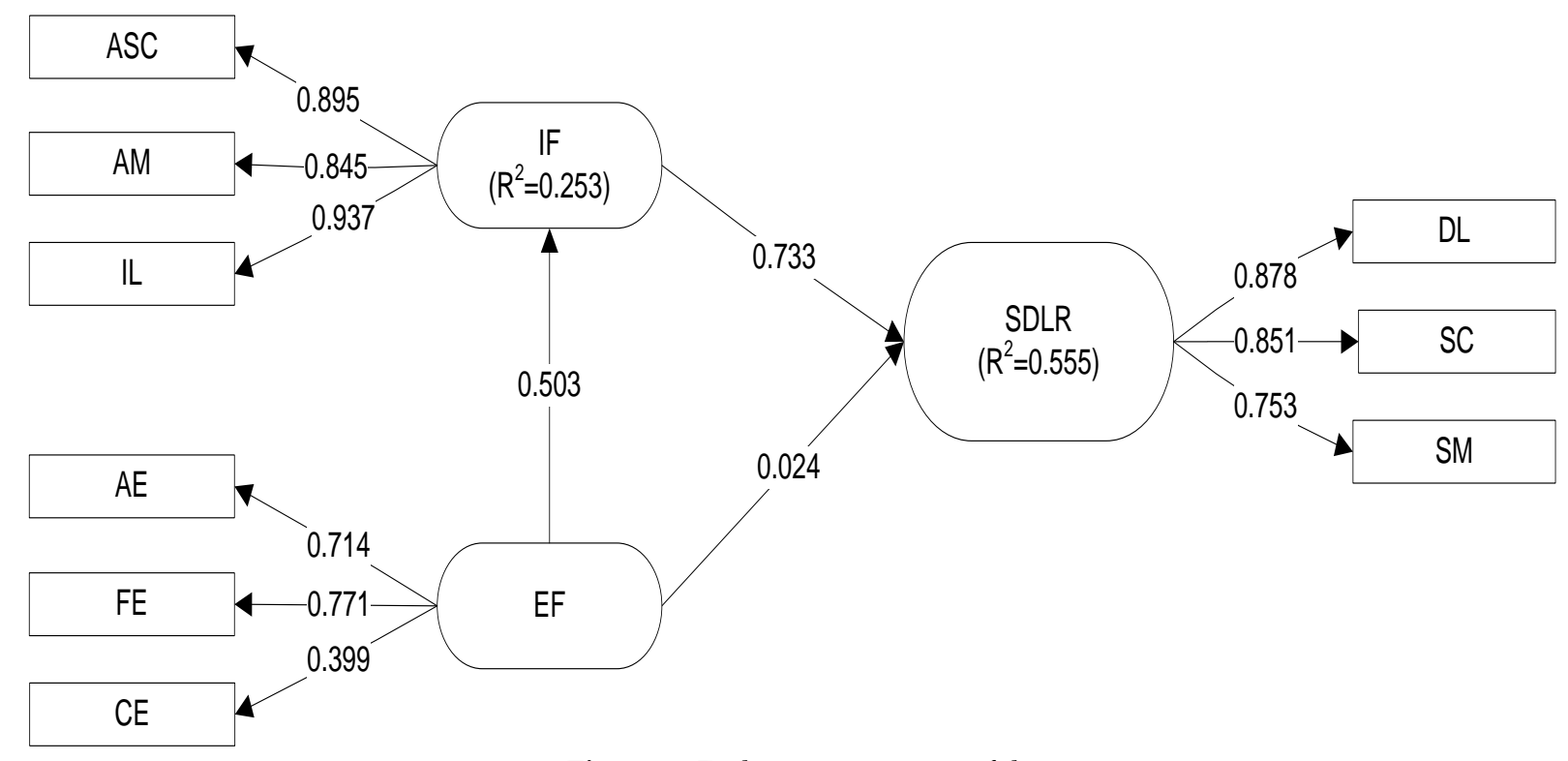

Source: Field data, SEM output

Figure-1. Early measurement model

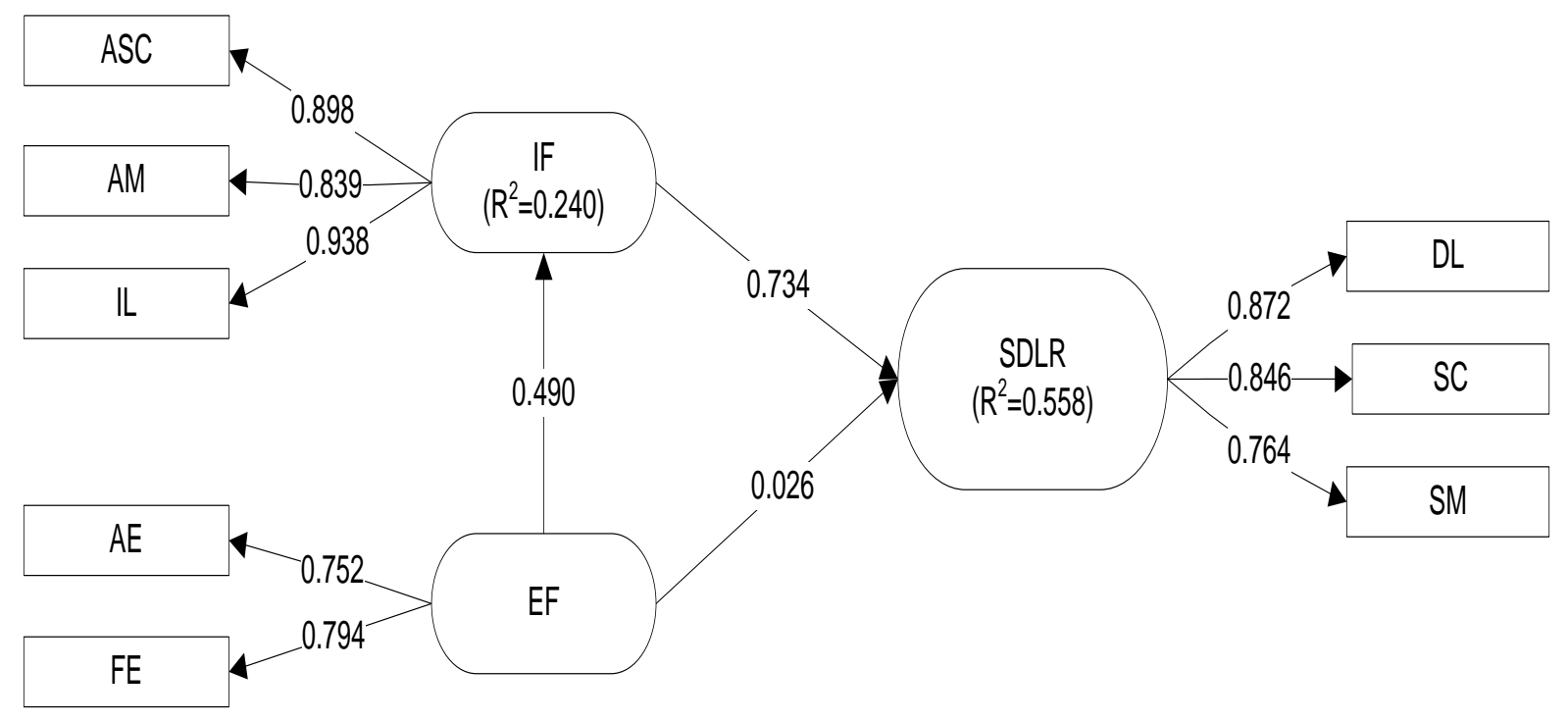

Source: Field data, SEM output

Figure-2. Final measurement model 
Table-1. Value of average variance extracted (AVE) and composite reliability

\begin{tabular}{l|l|l}
\hline & AVE & Composite Reliability \\
\hline External Factors & 0.598014 & 0.748303 \\
\hline Internal Factors & 0.797472 & 0.921804 \\
\hline SDLR & 0.686407 & 0.867481 \\
\hline \multicolumn{2}{l}{ Source: Field data, SEM output }
\end{tabular}

Discriminant validity testing conducted with the principle that different construct manifest variables should not be highly correlated (Ghozali, 2008). Table 2 shows that cross loading values between indicators with overall constructs have more than cross loading values with other constructs so that it can be said that the model has fulfilled the discriminant validity requirement.

Table-2. Cross loadings between indicators and constructs

\begin{tabular}{l|l|l|l}
\hline & External Factors & Internal Factors & SDLR \\
\hline Academic Environment & 0.751638 & 0.373878 & 0.274823 \\
\hline Family Environment & 0.794398 & 0.384564 & 0.319850 \\
\hline Achievement Motivation & 0.379248 & 0.839483 & 0.514056 \\
\hline Interest to Learn & 0.470152 & 0.938051 & 0.526406 \\
\hline Academic Self-concept & 0.458532 & 0.898746 & 0.554168 \\
\hline Self-Management & 0.323919 & 0.529409 & 0.763687 \\
\hline Desire to Learning & 0.318817 & 0.622414 & 0.872274 \\
\hline Self-Control & 0.312904 & 0.599044 & 0.845660
\end{tabular}

Source: Field data, SEM output

\subsubsection{Inner Model}

The inner model evaluation was performed to see the R-square $\left(\mathrm{R}^{2}\right)$ and path coefficient estimation. $\mathrm{R}^{2}$ value of endogenous latent variable is an endogenous construct variability that can be explained by the variability of exogenous construct. The result of analysis shows that structural model of internal factor yields $\mathrm{R}^{2}$ value of 0.240 , meaning that the diversity of internal factors explainable by the model is $24 \%$ while the remaining $76 \%$ explained by other factors outside the model. The structural model of self-directed learning readiness yield $\mathrm{R}^{2}$ value of 0.558 meaning that self-directed learning readiness diversity explainable by model is $55.8 \%$ while the rest $44.2 \%$ explained by other factor outside model (Figure 2).

The path coefficient estimation is an evaluation through the coefficient value and the effect of the exogenous latent variable on endogenous latent variable based on the value of t-statistical significance. Endogenous latent variables can be said to have significant effect if it has t-statistic value greater than t-table. T-table value at the real level of $5 \%$ is 1.96 .

The result of SEM analysis (Table 3) shows that at real level of $5 \%(\alpha=0.05)$, the external factors has significant effect on internal factors and self-directed learning readiness (t-statistic value $>1.96$ ). In addition to external factors, internal factors also significantly affect the self-directed learning readiness (t-statistic value $>$ 1.96). The influence of external factors on internal factors and the influence of internal factors on self-directed learning readiness are direct effect, while the influence of external factors on self-directed learning readiness is indirect effect.

Table-3. The result of SEM model estimation

\begin{tabular}{|c|c|c|c|c|c|}
\hline & \multicolumn{2}{|l|}{ Loading Factor } & \multirow{2}{*}{$\begin{array}{l}\text { Total } \\
\text { effect }\end{array}$} & \multirow{2}{*}{ T-statistic } & \multirow{2}{*}{ R-square } \\
\hline & Direct effect & Indirect effect & & & \\
\hline External Factor $->$ Internal Factor & $0.490^{*}$ & & 0.490 & 6.519 & 0.240 \\
\hline External Factor $->$ SDLR & 0.026 & $0.360^{*}$ & 0.385 & 4.421 & \\
\hline Internal Factor $->$ SDLR & $0.734^{*}$ & & 0.734 & 10.734 & 0.558 \\
\hline
\end{tabular}

Source: Field data, SEM output

\subsection{Discussion}

\subsubsection{The Influence of External Factors on Internal Factors}

The t-statistic value for the influence of external factors to the internal factor is 6.519. This indicates that the external factors significantly affect the internal factors of students. External factors have a direct positive effect on the internal factor is 0.490 . These result indicated that for every increase in the standard deviation of the external factor, the standard deviation of internal factors would increase 0.490. Students with supportive family environment, supportive academic environment and supportive community environment have achievement motivation, learning interest and high academic self-concept as well.

Based on the final measurement model, the indicators of the external factors are family environment and academic environment. The availability of a family environment and a supportive academic environment can motivate students to get a good achievement and increase their interest of learning.

The results of this study support the results of research conducted by Taheri et al. (2015) at Guilan University of Medical Science which shows that socio-cultural factors is the causal factor that yields a significant influence on achievement motivation, where university academic atmosphere is the biggest impact factor. Another similar study to this research is Mustafa and Zalim (2012) which the results of his research indicate that one of the factors influencing student interest is a situational factor consisting of family influence, influence of teacher and curriculum influence. 


\subsubsection{The Influence of External Factors on Self Directed Learning Readiness}

The t-statistic value for the influence of external factors to self-directed learning readiness is 4.421. This indicates that the external factors have a significant effect on student self-directed learning readiness. External factors gave an indirect positive effect on self-directed learning readiness of 0.360 through internal factors. This result indicates that internal factors are mediator for the effect of external factors to the self-directed learning readiness. The total influence of external factor to self-directed learning readiness is 0.385 .

The study results supported the results of research by Tarmidi (2010) which shows that the existence of social support from the family can increase the level of students' learning independence. One of the things parents can do to support student independence is to give their children the opportunity to solve their own problems. A study regarding self-directed learning readiness in Asia, especially Indonesia by Leatemia et al. (2016) by taking samples at five medical faculties, each faculty representing universities in five major islands of Indonesia, namely the islands of Sumatra, Java, Kalimantan, Sulawesi and Bali. The results of this study indicate that the academic environment in the form of learning facilities and academic atmosphere affected the level of self-directed learning readiness of students. Other research related to the influence of academic environment on self-directed learning readiness of students is research conducted by Huang (2008) where the result presented that students' perception regarding supportive learning environment significantly influence self-directed learning readiness of student. The study by Nurrokhmanti et al. (2016) is clarified that external factors affecting self-directed learning readiness consist of family and friend support, faculty facilities, problems encountered, peer relationships, and the environment influence of parents and friends.

\subsubsection{The Role of Internal Factors on the Self Directed Learning Readiness}

Besides the results that external factors contribute positively to the self-directed learning readiness of students through internal factors, the study also found that internal factors gave direct significant effects on the self-directed learning readiness. Based on the result of research, t-statistic value for the influence of internal factor to selfdirected learning readiness was equal to 10.734 with loading factor equal to 0.734 . This indicates that internal factors have a significant direct positive effect on self-directed learning readiness. Internal factor with the indicator variables i.e. achievement motivation, interest to learning and self-concept of academic gave positive effect to selfdirected learning readiness equal to 0.734 . This means that when the internal factors of students increases, will give an impact on the increase of their self-directed learning readiness, so that students who have achievement motivation, interest and high academic self-concept also has a high self-directed learning readiness.

The internal factors and internal motivation of the students have important role for student self-directed learning readiness (Nyambe et al., 2016). Students who have high of achievement motivation, interest to learn and academic self-concept will strive to manage their study time well and will strive to find the academic information they need from various sources independently. The desire for achievement and interest in learning make them trying independently to pursue the achievement they desire. The results of research by Saeid and Eslaminejad (2017) which showed that self-directed learning readiness correlated significantly with self-efficacy and achievement motivation of students in Payamnoor University.

\section{Conclusion and Suggestion}

\subsection{Conclusion}

Based on the data analysis' results, it can be concluded that:

1. External factors consisting of family environment and academic environment have a significant positive effect on internal factors (in the form of achievement motivation, interest to learning and academic selfconcept) and self-directed learning readiness of the fourth year medical students of Tadulako University. The effect of external factors on self-directed learning readiness is indirect.

2. Internal factors have an important role on the self-directed learning readiness of fourth year medical students of Tadulako University. The internal factors also proved to play a role as mediator of the relevance of external factors to the self-directed learning readiness.

\subsection{Suggestion}

1. For the Tadulako University, the management of the University can improve the student's selfdirected learning readiness by improving academic facilities and infrastructures, improve service quality and improve the competence of educators. The availability of facilities and academic infrastructure needed by students and providing a good service to students can support the creation of a good academic atmosphere so that it will increase the achievement motivation and learning interest of students which in the end also will increase their self-directed learning readiness.

2. For the next research. The further research is advice to include the other variables outside the model in this research such as self-efficacy, intelligence and experience that may influence self-directed learning readiness.

\section{References}

Abdillah, W. and H. Jogiyanto, 2015. Partial least square (PLS)-alternatif structural equation modeling (SEM) in business research. Yogyakarta: Andi Offset.

Cazan, A.M. and B.A. Schiopca, 2014. Self-directed learning, personality traits and academic achievement. Social and Behavioral Sciences, 27: 640-644. View at Google Scholar | View at Publisher

Conradie, P.W., 2014. Supporting self-directed learning by connectivism and personal learning environments. International Journal of Information and Education Technology, 4(3): 254-259. View at Google Scholar | View at Publisher

Fisher, M., J. King and J. Tague, 2001. Development of a self directed learning readiness scale for nursing education. Nurse Education Today, 21(7): 516-525. View at Google Scholar | View at Publisher

Fisher, M.J. and J. King, 2010. The self-directed learning readiness scale for nursing education revisited: A confirmatory factor analysis. Nurse Education Today, 30(1): 44-48. View at Google Scholar $\mid$ View at Publisher 
Ghozali, I., 2008. Structural equation modeling alternative method with partial least square (PLS). 2nd Edn., Semarang: Undip Publisher Agency.

Huang, M., 2008. Factors influencing self-directed learning readiness amongst Taiwanese nursing students [Disertasi]. Queesland (AU): Queesland University of Technology.

Jogiyanto, H.M., 2011. Concepts and applications structural equation modeling: Varian based in business research. Yogyakarta: UPP STIM YKPN.

Knowles, M.S., E.F. Holton and R.A. Swanson, 2005. The adult learner: The definitive classic in adult education and human resource development. Amsterdam (NL): Elsevier.

Leatemia, L.D., A.P. Susilo and H. Berkel, 2016. Self-directed learning readiness of Asian students: Student perspective on a hybrid problem based learning curriculum. International Journal of Medical Education, 7: 385-392. View at Google Scholar |View at Publisher

Levett-Jones, T.L., 2005. Self-directed learning implications and limitations for undergraduate nursing education. Nurse Educatin Today, 25(5): 363-368. View at Google Scholar $\mid$ View at Publisher

Mustafa, Z. and H. Zalim, 2012. Factors affecting students' interest in learning islamic education. Journal of Education and Practice, 3(13): 81-86. View at Google Scholar

Nurrokhmanti, H., M. Claramita and P.S. Utomo, 2016. Among students' internal factors, should motivation be used as one of recruitments for admission of medical students in Indonesia? Indosesian Journal of Medical Education, 5(2): 59-66. View at Google Scholar

Nyambe, H., Harsono and G.R. Rahayu, 2016. Factors influence self directed learning readiness of first, second and third years students at medical faculty of Hasanuddin University in PBL. Indosesian Journal of Medical Education, 5(5): 67-77.

Saeid, N. and T. Eslaminejad, 2017. Relationship between student's self-directedlearning readiness and academic self-efficacy and achievement motivation in students. International Education Studies, 10(1): 225-232. View at Google Scholar|View at Publisher

Taheri, M., E. Nasiri, F. Moaddab, N. Nayebi and A.A. Louyeh, 2015. Strategies to improve students educational achievement motivation at Guilan university of medical sciences. Research and Development in Medical Education, 4(2): 133-139. View at Google Scholar $\mid$ View at Publisher

Tarmidi, R.A.R.R., 2010. Correlation between social support of family and self directed learning on students of senior high scool. Journal of Psychology, 37(2): 216-223.

Wiley, K., 1983. Effects of a self-directed learning project and preference for structure on self-directed learning readiness. Nursing Research, 32(3): 181-185. View at Google Scholar | View at Publisher 